\title{
The Immune System in Human Milk: A Historic Perspective
}

\author{
Armond S. Goldman ${ }^{a}$ Sadhana Chheda ${ }^{b}$ \\ ${ }^{a}$ Department of Pediatrics, University of Texas Medical Branch, Galveston, TX, USA; ${ }^{b}$ Department of Pediatrics, Texas \\ Tech University Health Science Center, El Paso, TX, USA
}

\section{Keywords}

Human milk $\cdot$ Immunity $\cdot$ Medical history

\begin{abstract}
Background: Human milk contains a remarkable array of immunological agents that evolved over millions of years to protect the recipient human infant. Furthermore, much of the protection persists long after weaning. However, the scientists who first discovered some components of this immune system have rarely been acknowledged. Summary: The scientists who made many fundamental immunological discoveries concerning the immune system in human milk include Alfred François Donné, Paul Ehrlich, Lars Å. Hanson, and Jules Bordet. Based upon their discoveries, a wealth of antimicrobial, anti-inflammatory, and immunomodulating agents, and living, activated leukocytes in human milk were later revealed during the last half of the 20th and the first part of the 21 st century. Moreover, it was found that human milk enhances the colonization of commensal bacteria that aid to protect the human infant. Key Message: Their discoveries helped to revitalize breastfeeding in industrialized countries during the past several decades.
\end{abstract}

(c) 2021 S. Karger AG, Basel

\section{Introduction}

Although it is now widely accepted that human milk is the ideal nutrition for human infants, the frequency of breastfeeding in most industrialized countries fell from over $90 \%$ in the early twentieth century to about $5-10 \%$ in the 1970s [1]. That pattern gradually reversed. Now about $80 \%$ of mothers in those same countries breastfeed their infants, and the duration of breastfeeding has also risen. To a great extent, that occurred because of the recognition of a unique, exceptionally complex immune system in human milk [2] that evolved over millions of years to protect human infants [3]. As was reported in 2007 [4], certain protective properties of human milk were known in the 19th century. Indeed, to understand the complex immune system in human milk, it is helpful to recognize who made the initial discoveries and how those fundamental findings led to the current comprehension of the immune system in human milk and how it protects human infants.

karger@karger.com

www.karger.com/anm
Correspondence to:

Armond S. Goldman, armondsgoldman@gmail.com

\section{Karger"}




\section{Leukocytes in Human Milk}

Alfred François Donné [5] invented photomicroscopy in the early 1840s. Donné was born in Noyon, France. His father Adrien was a businessman. His mother was Marie Anne (nee) Gely. At age 2 years, he and his parents moved to Paris, France, where his parents expected him to study law. That was not to his liking. Instead, he decided to study medicine at the Université de Paris. He obtained his doctorate degree from that medical school in 1831. His thesis pertained to microscopy and chemistry.

Alfred Donné became a French public health physician-microbiologist. He became well known for discovering Trichomonas vaginalis, the microscopic appearance of leukemic cells, and important aspects of childhood hygiene and nutrition. Furthermore, he invented with Jean Bernard Léon Foucault the photoelectric microscope and photomicroscopy. The photomicroscope used a special glass plate method invented by Louis-Jacques-Mande Daguerre [6].

In addition, Donné discouraged wet nursing and advocated breastfeeding by the infant's own mother [7]. Without realizing it, he was ahead of his times because of the later discoveries of reciprocal relationships between the production of many of the immunologic components of human milk and their synthesis by the recipient infant. Furthermore, it was not known at that time that certain viruses such as cytomegalovirus could be transmitted through milk from infected women. Even so, that viral transmission does not lead to disease in the recipient infant. Of more importance, the discovery of entero-mammary and broncho-mammary gland pathways led to the realization that mothers provided specific antibodies to protect their infants from infections within their environments.

In 1845, Donné [8] published an atlas that depicted photomicrographs of many different types of human cells. One of the most intriguing one was of human milk. Human milk was found to contain many round bodies of various sizes. Because stains for cells were not devised until the end of the nineteenth century, the cells were called Les Corpuscles de Donné for another 5 decades. Once appropriate stains became available, it was realized that those bodies were milk fat globules and cells. However, because the majority of the cells were filled with vacuoles, they were difficult to identify until more specific cell markers were developed.

In 1968, it was ascertained that human milk contains living neutrophils, macrophages, and T cells [9]. Later, it was discovered that all human milk leukocytes are acti- vated $[10,11]$, whereas few activated leukocytes are in peripheral blood. Recently, it was recognized that epithelial stem cells are also in human milk [12]. The in vivo actions of cells in human milk are as yet undetermined.

\section{Antibodies in Human Milk}

Antibodies in a mammalian milk were first demonstrated by the famous German immunologist-physician Paul Ehrlich [13], who received the Nobel Prize in Physiology and Medicine in 1908. Ehrlich was born in Strehlen, Prussia. His mother was Rosa (nee) Weigert. His father, Ismar, was an innkeeper, a distiller of liquors, and a leader of the local Jewish community. Early in his life, Paul became interested in staining tissues from his cousin Karl Weigert, who was an academic pathologist. Ehrlich's interest in tissue staining continued during his medical studies at the Universities of Breslau, Freiburg, and Leipzig.

Afterward, Ehrlich became the Assistant Medical director of the Charité - Universitätsmedizin Berlin. There he developed cellular staining methods. He contracted pulmonary tuberculosis at that time. For that reason, he traveled to Egypt to recover from the illness. When the disease remitted, he returned to Berlin in 1889, where he opened a private laboratory. Soon afterward, he became the clinical supervisor for research concerning tuberculosis at the City Hospital Berlin-Moabit. Within a year, he was provided a laboratory at the Institut für Infektionskrankheiten in Berlin. In 1896, he became the head of the Institut für Serumforschung und Serumprüfung, BerlinSteglitz.

Ehrlich became known for developing staining techniques that permitted lymphocytes, neutrophils, eosinophils, basophils, and mast cells to be identified. He improved the staining of tubercle bacilli by showing its acid fastness, standardized the production of diphtheria antitoxin, developed the side-chain theory that led to understanding B cells and the multiplicity of antibody bindings, predicted autoimmunity, and devised Salvarsan, the first chemical agent used to treat syphilis.

Ehrlich [14, 15] also founded pediatric immunology by his cross-fostering experiments in mice conducted in 1891 that demonstrated that specific antibodies to toxins of ricin (found in seeds of castor oil plant) or abrin (found in seeds of rosary pea) were passed via the placenta or the mammary gland. That important discovery was virtually ignored until the mid-20th century when others began to explore whether antibodies were in human milk. 
The predominant immunoglobulin isoform in human milk, secretory IgA, was first detected by the physicianimmunologist - Dr. Lars Å. Hanson [16] from Göteborg, Sweden in 1961. Before then, Hanson was influenced by one of his teachers, the Swedish microbiologist - immunologist Örjan T. G. Ouchterlony [17] (1914-2004) from Göteborg University, who first devised double immunodiffusion in gels to identify antigens and antibodies. That method led to the development of immunoelectrophoresis in 1953 by P. Graber and C. A. Williams, Jr. [18] from l'Institut Pasteur. Hanson [16] showed by immunoelectrophoresis that IgA was the most prominent immunoglobulin in human milk.

Lars A. Hanson was born in Naverstad, Sweden. During his youth, he was an excellent student. Early on he was devoted to caring for others and to science. After graduating with $\mathrm{MD}$ and $\mathrm{PhD}$ degrees from the Universität Göteborg, he received further education in the Pasteur Institute in 1958, Rockefeller University during 1962 and 1963, and the National Institutes of Health in the USA from 1979 to 1980 . He became a pediatric immunologist. He was appointed as Assistant Professor at the Universität Göteborg in 1961 and was promoted to Professor of Immunology and Head of Clinical Immunology in 1977. He continued to work at the Universität Göteborg until he retired in 2020.

Over the course of his career, he became a leading researcher concerning the immune system in human milk. For his achievements, he received many awards, including the Robert Koch Prize for a major discovery in biomedical science in 1981, the Oskar-Medin Prize, the Nutricia International Award in 2004, and the Macy-György Prize from the International Society for Research in $\mathrm{Hu}$ man Milk and Lactation in 2004 for his outstanding accomplishments in research concerning the immunology of human milk [19].

Later, Dr. Per Brandtzaeg [20] from the Oslo University Hospital, Rikshospitalet, found that IgA molecules in human milk were dimers complexed to secretory component, a remnant of the IgA receptor on the basolateral surface of mammary gland epithelial cells. Afterward, it was found that secretory IgA in human milk resisted intestinal digestion because of its dimeric structure and the preponderance of lambda light chains in IgA [21].

It was remarkable that specific antibodies against many mucosal pathogens were in human milk, but their origin was unclear. In 1989, Lars A. Hanson and his colleagues [22] found preliminary evidence that the cells that produce those IgA antibodies came from the maternal intestinal tract. The formation of the cells that produce
IgA in human milk was elucidated by discovering their origin from the maternal intestinal tract. The path from the maternal intestines to the mammary gland (the entero-mammary gland pathway) begins when antigen stimulated, IgA positive B cells in ileal Peyer's patches migrate sequentially to intestinal lymphatics, mesenteric lymph nodes, the cisterna chyli, the thoracic duct, the vascular circulation, and the mammary gland [23]. That accounts for the vast repertoire of specific antibodies in human milk against intestinal microbes. A similar pathway was found for the creation of secretory $\operatorname{IgA}$ antibodies in human milk to respiratory pathogens [24].

\section{Lysozyme}

The British microbiologist Alexander Fleming observed in 1921 when his nasal secretions accidentally dripped onto an agar plate, staphylococci in the culture were lysed [25]. He found the lytic activity in human nasal secretions, tears, sputum, parotid secretions, and serum [26]. He named the activity lysozyme. He did not examine whether that lytic activity was in human milk. Afterward, Jules Bordet, the Belgian immunologist-microbiologist, who discovered complement, anaphylatoxins, the use of antibodies to detect certain infections, and the bacterium that causes pertussis [27], found lysozyme activity in human milk [28].

Jules Bordet was born in 1870 at Soignies, Belgium. His mother was Thérèse Célestine (nee) Vandenbeele. His father, Charles-Henri, was the schoolmaster at the École Moyenne de Schaerbeek near Brussels. Jules was interested in chemistry at an early age. When he was age 16 years, he enrolled in the Faculté de Médecine of the Université Libre de Bruxelles. After graduation, Jules worked as a physician in a coastal community in West Flanders. In 1894, he received funds from the Belgian government to study at l'Institut Pasteur in the laboratory of Ilya Ilyich Metchnikoff, the founder of cellular immunology. After Bordet returned to Belgium to head a new research institute, he discovered lysozyme activity (insensitive to the temperature that inactivated complement) in human colostrum and milk [28]. It was the first soluble immune agent found in human milk. The molecular structure and enzymatic activity of lysozyme in human milk were ascertained in 1961 by Pierre Jollés (1927) and Jacqueline Jollés [29] from the Université de Paris. Much lesser amounts of lysozyme were found in cow's milk.

\section{Lactoferrin}

A red-colored protein was found in bovine milk by the Danish biochemist Soren Peter Lauritz Sørenson (1868- 
1939) in 1939 [30]. The study was conducted with his wife and long-time professional colleague Margrethe (nee Høyrup).

Soren Sørenson was born in Havrebjerg, Denmark in 1868 [31]. His father, Hans, was a farmer. Soren became interested in science at an early age. He initially went to medical school but soon switched to biochemistry. $\mathrm{He}$ obtained a degree in that subject in 1891. He invented the groundbreaking $\mathrm{pH}$ scale and investigated amino acids, enzymes, and many different proteins. He became the leader of the Chemical Department at the Carlsberg Laboratory in Copenhagen from 1901 until his death in 1939 at age 70 years. He received many honors for his accomplishments from Denmark, Finland, Sweden, Spain, France, Belgium, Poland, England, and the USA.

In 1951, K. H. Schäfer [32] found that the red proteinbound iron and was in human milk. In 1960, the protein was isolated from human milk by Merton L. Groves [33] (1914-1999) from the US Department of Agriculture and by J. Montreuil [34] from France. Because of its chemical similarities to transferrin and its binding to ferrous iron, it was named lactoferrin [35].

Bengt Johansson [36] from the Universität Göteborg isolated crystals of human milk lactoferrin in 1969. At about the same time, Bryan F. Anderson and his colleagues [37] in the Massey University of New Zealand found that human lactoferrin was a glycoprotein with 2 globular lobes, each of which has a binding site for ferric iron. Gun-Britt Fransson and Bo Lönnerdal [38] from the Universität Uppsala, Sweden, found that lactoferrin in human milk was $>90 \%$ iron-free. Thus, the iron-binding sites were free to compete with siderophilic bacteria and fungal enterochelin for ferric iron [39]. The chelation of ferric iron disrupts the proliferation of those pathogens.

\section{Discovery of Many Other Antimicrobial Agents in Human Milk}

With the advent of many new laboratory methods in the latter half of the twentieth century, a plethora of antimicrobial agents was discovered in human milk. The human milk agents were substantially different from those in bovine milk used to feed human infants. The agents included a-lactalbumin that kills Streptococcus pneumoniae [40]; the chemokine CCL28 that kills Candida albicans and many gram-positive and gram-negative bacteria [41]; the membranes and mucin from milk globules that inhibit the binding of S-fimbriated Escherichia coli to human epithelium [42]; lactadherin from milk globules that inhibits rotavirus replication [43]; prototypic long pentraxin that facilitates phagocytosis of Pseudomonas aeruginosa and Aspergillus fumigatus [44]; and defensins that are antibacterial [45].

Moreover, a wealth of human milk oligosaccharides was discovered that are receptor analogues that inhibit the binding of certain enteric or respiratory bacterial pathogens and their toxins to epithelial cells [46]. How oligosaccharides were discovered in human milk and found to be many-fold higher than in cow's milk were also revealed in that report [46].

In the latter part of the 19th century, it was noted that breastfed infants were less prone to die from intestinal infections than those that were not breastfed. The German-Austrian pediatrician Theodore Escherich (18571911) discovered in 1886 the bacterium later named after him (Escherichia coli) [47]. The Austrian pediatrician Ernst Moro (1874-1951), who was a past student of Escherich, and the French pediatrician Henry Tissier at the Pasteur Institute in Paris, discovered soon afterward that certain types of intestinal bacteria were associated with health or certain diseases in human infants $[47,48]$. Decades later, a chemist, Richard Kuhn, and a pediatrician, Paul György, who was a past student of Moro, discovered that the growth of Bifidobacterium bifidum was promoted by a group of oligosaccharides [49]. It was later confirmed that the types of oligosaccharides in human milk and bovine milk were different [46]. Furthermore, the quantity of oligosaccharides in human milk was found to exceed the total milk proteins during all phases of lactation [46]. It was also ascertained that human milk contains over a hundred different types of oligosaccharides [46]. These agents help to control the intestinal microbiome and have many other important defenses for breastfed infants [46].

\section{Anti-Inflammatory Agents in Human Milk}

In addition to leukocytes and antimicrobial agents in human milk, it was reported in 1986 that human milk contains many anti-inflammatory agents [50]. The concept came about when Armond Goldman and his associates, including Lars $\AA$. Hanson, questioned why breastfed infants displayed few if any symptoms during shigellosis, even when shigella was cultured from the nipples of the breastfeeding women [51]. Prior research publications revealed that anti-inflammatory agents were in human milk [50]. However, those reports were not primarily directed toward understanding human milk but to the presence of those agents in a host of human tissues and exter- 
nal secretions. The anti-inflammatory agents included epithelial growth promoters that strengthen mucosal barriers [52]; antioxidants [53]; lactoferrin that interferes with some complement components [54]; protease inhibitors [55]; agents that bind to pro-inflammatory substrates such as lysozyme to elastin [56] and lactoferrin to the lipopolysaccharide, lipid A [57]; and the cytoprotective agents prostaglandins $\mathrm{E}_{1}, \mathrm{E}_{2}$, and $\mathrm{F}_{2 \alpha}$ [58].

Enzymes that degrade inflammatory mediators were also found in human milk. For instance, platelet-activating factor (PAF) was discovered to be degraded by human milk PAF-acetylhydrolase [59]. That correlated with the developmental delay in the production of PAF-acetylhydrolase in human infants [60].

\section{Immunomodulators in Human Milk}

In the 20th century, it was found that certain chronic diseases were less frequent in older children and adults if they had been breastfed during infancy. Epidemiologic studies showed that children breastfed during infancy were at less risk for certain diseases mediated by immunologic, inflammatory, or oncogenic mechanisms. The diseases included type 1 and type 2 diabetes mellitus [61, 62], childhood leukemia and lymphoma [63], ulcerative colitis [64], and Crohn disease [65]. Furthermore, it was found that breastfeeding leads to a more rapid development of systemic and secretory antibody responses [66, 67] and to increased amounts of secretory $\operatorname{IgA}$ in urine [68]. Those systemic responses were far removed, anatomically and temporally, and thus could not be accounted for by passive transfer from human milk. These clinical observations suggested that immunomodulating agents were in human milk.

A salient discovery was made by the Australian immunologist, Jacques Francis Albert Pierre Miller [69]. His father, Maurice, was an interpreter for the French Army during the First World War. Jacques Miller was born in 1931 in Nice, France. His last name was originally Meunier. His childhood was spent sequentially in France, Switzerland, and China, where his father was manager of the Shanghai Franc-Chinese Bank in 1939. In 1941, his family obtained British passports, changed the family's last name to Miller, and migrated to Australia.

Jacques Miller was educated at St. Aloysius' College in Sydney, Australia. He studied medicine at the University of Sydney and did his first laboratory research in Professor Patrick de Burgh's laboratory, where he investigated virus infections. In 1958, Miller went to the United King- dom on a Fellowship from the University of Queensland. He was accepted to the Chester Beatty Research Institute of Cancer Research and as a PhD student at the University of London. Miller studied the pathogenesis of murine lymphocytic leukemia. In doing so, he examined whether thymectomy at birth prevented leukemia.

At the time of his graduate school studies, the thymus was thought to have no function, except as a burial ground for lymphocytes. Miller showed in 1962 that mice thymectomized at birth did not reject foreign tissues and could not resist many infections [70]. Thus, he discovered that the thymus was vital for the development and function of adaptive immunity (immunity specific for an antigen). He later discovered that mammalian lymphocytes were separated into what were later called $\mathrm{T}$ cells and $\mathrm{B}$ cells and that interactions of those lymphocytes led to antibody production. He then found that the thymus produces $\mathrm{T}$ cells and removes self-reactive $\mathrm{T}$ cells.

Miller noticed that mice thymectomized later in life were not immunodeficient. Furthermore, he found that thymectomized neonatal mice seemed normal until they were weaned. Afterward, they became lymphopenic, could not reject allografts, and often died. It was likely that the delay in producing immunodeficiency in mice thymectomized at birth was due to agents in murine milk. Miller did not investigate that possibility.

It is now known that thymic growth [71], thymic function [72], and T-cell emigration from the thymus [73] are greater in breastfed than nonbreastfed human infants. Several cytokines in human milk are most likely responsible for the increases in thymic and T-cell functions [74, 75].

\section{Characteristics of the Immune System in Human Milk}

The discovery of antimicrobial agents, anti-inflammatory factors, immunoregulators, and living activated leukocytes led to the concept of an immune system in human milk $[76,77]$. The components of the complex human milk immune system were found to have many common features. (1) Many are multifunctional, in that they are both antimicrobial and anti-inflammatory, or immunoregulatory and anti-inflammatory $[41,46,57,75,77]$. (2) They often act synergistically [77, 78]. (3) Most of the components undergo dynamic quantitative changes in different phases of lactation [77]. In that respect, as the production of most of the agents in human milk declines, their production by the recipient infant rises. (4) Virtually all are more resistant to enzymatic degradation than 
the protective agents in human blood such as IgG [77]. (5) Certain agents are compartmentalized. For example, some are in milk fat globules $[43,79,80]$, whereas others such as TNF- $\alpha$ are bound to soluble receptors in human milk [81] (6) Some partially degraded agents such as milk lipids are antimicrobial $[78,82]$. (7) Although most of the agents evolved to protect the mucosa of the intestinal and respiratory tracts, some have systemic effects [66-68].

\section{Epilogue}

Research conducted over a century and a half revealed that human milk contains a complex, dynamic, multifactorial immune system that developed over millions of years of evolution. Yet, the realizations only came about because of the insights and efforts of certain scientists. They, as well as the information they discovered, were remarkable.

The pioneers who launched the discovery of the immune system in human milk had certain common attributes. (1) They had great levels of curiosity. (2) They displayed heightened powers of deductive and inductive reasoning. (3) They innovated methods to explore medical mysteries. (4) They directed their research toward lessening human diseases - toward improving human health.

Their scientific achievements greatly helped to lead to the realization that human milk is the ideal nutrition for human infants. The past pioneers can be emulated since much more needs to be learned about the immune system in human milk [75]. That is the hope for the future.

\section{Acknowledgements}

We thank Dr. Daniel A. Goldman for his insightful suggestions.

\section{Statement of Ethics}

Ethical Committee approval was not required since the research was limited to a review of the accomplishments of scientist who researched the immune system in human milk.

\section{Conflict of Interest Statement}

The authors have no conflicts of interest to declare.

\section{Funding Sources}

The authors have no funding sources to declare.

\section{Author Contributions}

The 2 authors, Armond S. Goldman and Sadhana Chheda, participated in writing this manuscript.

\section{References}

1 Eckhardt KW, Hendershot GE. Analysis of the reversal in breast feeding trends in the early 1970s. Public Health Rep. 1984;99:410-5.

2 Goldman AS, Chheda S, Keeney SE. Immunology of human milk and host immunity. In: Polin RL, Abman S, Rowitch DH, Benitz W, editors. Fetal and neonatal physiology. 6th ed. Philadelphia (PA): Elsevier; 2021.

3 Goldman AS. Evolution of immune functions of the mammary gland and protection of the infant. Breastfeed Med. 2012;7:132-42.

4 Wheeler TT, Hodgkinson AJ, Prosser CG, Davis SR. Immune components of colostrum and milk--a historical perspective. J Mammary Gland Biol Neoplasia. 2007;12:237-47.

5 Diamantis A, Magiokinis E, Androustsos G. Alfred François Donné (1801-1878). J Med Biogr. 2009;17:81-7.

6 Classics of science: the daguerreotype. The science news-letter. 374th ed. Society for Science \& the Public; 1928. Vol. 13.
7 Donné A. Du Lait et en particulier de celui des Nourrices: considéré sous le rapport de ses bonnes et de ses mauvaises qualités nutritives et de altérations. Paris: Val. Repert. III; 1837.

8 Donné AF. Cours de microscopie. Paris: J.B. Bailliére; 1845.

9 Smith CW, Goldman AS. The cells of human colostrum. I. In vitro studies of morphology and functions. Pediatr Res. 1968;2:103-9.

10 Wirt DP, Adkins LT, Palkowetz KH, Schmalstieg FC, Goldman AS. Activated and memory T lymphocytes in human milk. Cytometry. 1992;13:282-90.

11 Keeney SE, Schmalstieg FC, Palkowetz KH, Rudloff HE, Goldman AS. Activated neutrophils and neutrophil activators in human milk. Increased expression of CD11b and decreased expression of L-selectin. J Leukocyte Biol. 1993;54:97-104.

12 Hassiotou F, Hartmann PE. At the dawn of a new discovery: the potential of breast milk stem cells. Adv Nutr. 2014;5:770-8.
13 Schmalstieg FC Jr, Goldman AS. Ilya Ilich Metchnikoff (1845-1915) and Paul Ehrlich (1854-1915): the centennial of the 1908 nobel prize in physiology or medicine. J Med Biogr. 2008;16:96-103.

14 Ehrlich P. Experimentelle untersuchangen über immunität. I Über ricin. Dtsch Med Wochenschr. 1891;17:976-9.

15 Ehrlich P, Hubner W. Experimentelle untersuchangen über immunität. II. Über abrin. Dtsch Med Wochenschr. 1891;17:1218-9.

16 Hanson LÅ. Comparative immunological studies of the immune globulins of human milk and of blood serum. Int Arch Allergy Appl Immunol. 1961;18:241-67.

17 Ouchterlony O. Antigen-antibody reactions in gels. Acta Pathol Microbiol Scand. 1949;26: 507-15.

18 Grabar P, Williams CA Jr. Méthode permettant l'étude conjugée des propriétés électrophorétiques et immunochemiques d'un mélange de proteins. Application au serum sanguine. Biochem Biophys Acta. 1953;10:193-4. 
19 Hanson LA. Macy-György prize lecture: my milky way. Adv Exp Med Biol 2009; 639:28390.

20 Brandtzaeg P. Polymeric IgA is complexed with secretory component (SC) on the surface of human intestinal epithelial cells. Scand J Immunol. 1978;8:39-52.

21 Molé CM, Montagne PM, Béné MC, Faure GC. Sequential assay of human milk immunoglobulins shows a predominance of lambda chains. Lab Invest. 1992;67:147-51.

22 Ahlstedt S, Carlsson B, Hanson LÅ, Goldblum RM. Antibody production by human colostral cells. I. Immunoglobulin class, specificity, and quantity. Scand J Immunol. 1975; 4:535-9.

23 Roux ME, McWilliams M, Phillips-Quagliata JM, Weisz-Carrington P, Lamm ME. Origin of IgA-secreting plasma cells in the mammary gland. J Exp Med. 1977;146:1311-22.

24 Fishaut M, Murphy D, Neifert M, McIntosh $\mathrm{K}$, Ogra PL. Bronchomammary axis in the immune response to respiratory syncytial virus. J Pediatr. 1981;99:186-91.

25 Fleming A. On a remarkable bacteriolytic element found in tissues and secretions. Proc $\mathrm{R}$ Soc Lond B. 1922;93(653):306.

26 Fleming A, Allison VD. Observations on a bacteriolytic substance ("lysozyme") found in secretions and tissues. Brit J Exp Path. 1922;3: 252-60.

27 Schmalstieg FC Jr, Goldman AS. Jules Bordet (1870-1961): a bridge between early and modern immunology. J Med Biogr. 2009;17: 217-24.

28 Bordet J, Mordet M. Le pouvoir bactériolytique du colostrum et du lait. Comptes Rendus des Séaces de L'Academie des Sciences. 1924;179:1109-13.

29 Jollès P, Jollès J. Lysozyme from human milk. Nature. 1961;192(4808):1187-8.

30 Sørensen M, Sørensen SPL. The proteins in whey. Comp rend des Travaux du Laboratoire de Carlsberg Série Chem. 1939;23:55-90.

31 Cosbie AJC. Prof. S. P. L. Sørensen. Nature. 1939;143(3624):629.

32 Schäfer KH. Elektrophoretische untersuchungen zum milcheiweissproblem. Monatsschr Kinderheilkd. 1951;99:69-71.

33 Groves ML. The isolation of a red protein from milk2. J Am Chem Soc. 1960;82(13): 3345-50.

34 Montreuil J, Tonnelat J, Mullet S. Preparation and properties of lactosiderophilin (lactotransferrin) of human milk. Biochim Biophys. 1960;45:413-21.

35 Blanc B, Isliker HC. Isolement et caractérisation de la protéine rouge sidérophile du lait maternal: la lactoferrine. Helv Physiol Pharmacol Acta. 1961;19:C13-4.

36 Johansson BG. Isolation of crystalline lactoferrin from human milk. Acta Chem Scand. 1969;23:683-4

37 Anderson BF, Baker HM, Dodson EJ, Norris GE, Rumball SV, Waters JM, et al. Structure of human lactoferrin at 3.2- $\AA$ resolution. Proc Natl Acad Sci U S A. 1987;84:1769-73.
38 Fransson GB, Lönnerdal B. Iron in human milk. J Pediatr. 1980;96:380-4.

39 Bullen JJ, Rogers HJ, Leigh L. Iron-binding proteins in milk and resistance to Escherichia coli infection in infants. Br Med J. 1972;1:6975.

40 Hâkansson A, Svensson M, Mossberg AK, Sabharwal H, Linse S, Lazou I, et al. A folding variant of alpha-lactalbumin with bactericidal activity against Streptococcus pneumoniae. Mol Microbiol. 2000;35:589-600.

41 Hieshima K, Ohtani H, Shibano M, Izawa D, Nakayama T, Kawasaki Y, et al. CCL28 has dual roles in mucosal immunity as a chemokine with broad-spectrum antimicrobial activity. J Immunol. 2003;170:1452-61.

42 Schroten H, Hanisch FG, Plogmann R, Hacker J, Uhlenbruck G, Nobis-Bosch R, et al. Inhibition of adhesion of S-fimbriated Escherichia coli to buccal epithelial cells by human milk fat globule membrane components: a novel aspect of the protective function of mucins in the nonimmunoglobulin fraction. Infect Immun. 1992;60:2893-9.

43 Peterson JA, Hamosh M, Scallan CD, Cerian RL, Henderson TR, Mehta NR, et al. Milk fat globule glycoproteins in human milk and in gastric aspirates of mother's milk-fed preterm infants. Pediatr Res. 1998;44:499-506.

44 Jaillon S, Mancuso G, Hamon Y, Beauvillain C, Cotici V, Midiri A, et al. Prototypic long pentraxin PTX3 is present in breast milk, spreads in tissues, and protects neonate mice from Pseudomonas aeruginosa lung infection. J Immunol. 2013;191:1873-82.

45 Jia HP, Starner T, Ackermann M, Kirby P, Tack BF, McCray PB. Abundant human betadefensin-1 expression in milk and mammary gland epithelium. J Pediatr. 2001;138:109-12.

46 Bode L. Human milk oligosaccharides: every baby needs a sugar mama. Glycobiology. 2012;22:1147-62.

47 Farré-Maduell E, Casals-Pascual C. The origins of gut microbiome research in Europe: from Escherich to tissier. Hum Microbiome J. 2019;14:100065.

48 Montreuil J, Renner B, Sawatzki GG. The saga of human milk gynolactose, new perspectives in infant nutrition. Stuttgart (NY): Georg Thieme Verlag; 1992.

49 György P, Hoover JR, Kuhn R, Rose CS. Bifidus factor. III. The rate of dialysis. Arch Biochem Biophys. 1954;48:209-13.

50 Goldman AS, Thorpe LW, Goldblum RM, Hanson LA. Anti-inflammatory properties of human milk. Acta Paediatr Scand. 1986;75: 689-95.

51 Mata LJ, Urrutia JJ, García B, Fernández R, Béhar M. Shigella infection in breast-fed Guatemalan Indian neonates. Am J Dis Child. 1969;117:142-6.

52 Carpenter G. Epidermal growth factor is a major growth-promoting agent in human milk. Science. 1980;210:198-9.
53 Buescher ES, McIlheran SM. Colostral antioxidants: separation and characterization of two activities in human colostrum. J Pediatr Gastroenterol Nutr. 1992;14:47-56.

54 Kijlstra A, Jeurissen SH. Modulation of classical C3 convertase of complement by tear lactoferrin. Immunology. 1982;47:263-70.

55 Lindberg T, Ohlsson K, Weström B. Protease inhibitors and their relation to protease activity in human milk. Pediatr Res. 1982;16:47983.

56 Park PW, Biedermann K, Mecham L, Bissett DL, Mecham RP. Lysozyme binds to elastin and protects elastin from elastase-mediated degradation. J Invest Dermatol. 1996;106: 1075-80.

57 Caccavo D, Pellegrino NM, Altamura M, Rigon A, Amati L, Amoroso A, et al. Antimicrobial and immunoregulatory functions of lactoferrin and its potential therapeutic application. J Endotoxin Res. 2002;8:403-17.

58 Shimizu T, Yamashiro Y, Yabuta K. Prostaglandin E1, E2, and F2 alpha in human milk and plasma. Biol Neonate. 1992;61:222-5.

59 Furukawa M, Narahara H, Yasuda K, Johnston JM. Presence of platelet-activating factor-acetylhydrolase in milk. J Lipid Res. 1993; 34:1603-9.

60 Caplan M, Hsueh W, Kelly A, Donovan M. Serum PAF acetylhydrolase increases during neonatal maturation. Prostaglandins. 1990; 39:705-14

61 Norris JM, Scott FW. A meta-analysis of in fant diet and insulin-dependent diabetes mellitus: do biases play a role. Epidemiology. 1996;7:87-92.

62 Ziegler AG, Schmid S, Huber D, Hummel M, Bonifacio E. Early infant feeding and risk of developing type 1 diabetes-associated autoantibodies. JAMA. 2003;290:1721-8.

63 Davis MK, Savitz DA, Graubard BI. Infant feeding and childhood cancer. Lancet. 1988;2: 365-8.

64 Koletzko S, Griffiths A, Corey M, Smith C, Sherman P. Infant feeding practices and ulcerative colitis in childhood. BMJ. 1991;302. $1580-1$.

65 Koletzko S, Sherman P, Corey M, Griffiths A, Smith C. Role of infant feeding practices in development of Crohn's disease in childhood. BMJ. 1989;298:1617-8.

66 Stephens S, Kennedy CR, Lakhani PK, Brenner MK. In-vivo immune responses of breast- and bottle-fed infants to tetanus toxoid antigen and to normal gut flora. Acta Paediatr Scand. 1984;73:426-32.

67 Stephens S. Development of secretory immunity in breast fed and bottle fed infants. Arch Dis Child. 1986;61:263-9.

68 Goldblum RM, Schanler RJ, Garza C, Goldman AS. Human milk feeding enhances the urinary excretion of immunologic factors in low birth weight infants. Pediatr Res. 1989;25: 184-8.

69 Mellor L, Miller JFAP. Faculty of medicine online museum and archive. Australia: The University of Sydney; 2008. 
70 Miller JFAP. Effect of neonatal thymectomy on the immunological responsiveness of the mouse. Proc R Soc Lond B. 1962;156(964): 415-28.

71 Hasselbalch H, Engelmann MD, Ersboll AK, Jeppesen DL, Fleischer-Michaelsen K. Breastfeeding influences thymic size in late infancy. Eur J Pediatr. 1999;158:964-7.

72 Ngom PT, Collinson AC, Pido-Lopez J, Henson SM, Prentice AM, Aspinall R. Improved thymic function in exclusively breastfed infants is associated with higher interleukin 7 concentrations in their mothers' breast milk. Am J Clin Nutr. 2004;80:722-8.

73 Field CJ, Thomson CA, Van Aerde JE, Parrott A, Euler A, Lien E, et al. Lower proportion of CD45R0+ cells and deficient interleukin-10 production by formula-fed infants, compared with human-fed, is corrected with supplementation of long-chain polyunsaturated fatty acids. J Pediatr Gastroenterol Nutr. 2000; 31:291-9.

74 Garofalo R. Cytokines in human milk. J Pediatr. 2010;156:S36-40.

75 Goldman AS. Future research in the immune system of human milk. J Pediatr. 2019;206: 274-9.

76 Goldman AS, Smith CW. Host resistance factors in human milk. J Pediatr. 1973;82:1082-90.

77 Goldman AS. The immune system of human milk: antimicrobial, antiinflammatory, and immunomodulating properties. Pediatr Infect Dis J. 1993;12:664-72.

78 Isaacs CE. Human milk inactivates pathogens individually, additively, and synergistically. J Nutr. 2005;135:1286-8.
79 Magi B, Ietta F, Romagnoli R, Liberatori S, Pallini V, Bini L, et al. Presence of macrophage migration inhibitory factor in human milk: evidence in the aqueous phase and milk fat globules. Pediatr Res. 2002;51:61924.

80 Cattaneo C, Caramaschi A, Uga E, Braghin M, Cosi G, Peila C, et al. Analysis of toll-like receptors in human milk: detection of membrane-bound and soluble forms. J Immunol Res. 2019;2019:1-12.

81 Buesher EWS, Malinowska I. Soluble receptors and cytokine antagonists in human milk. Pediatr Res. 1996;34:839-44.

82 Issacs CE, Thormar H, Pessolano T. Membrane-disruptive effect of human milk: inactivation of enveloped viruses. J Infect Dis. 1986;154:966-71. 